\title{
REMOTE MATERIAL HANDLING IN THE YUCCA MOUNTAIN WASTE PACKAGE CLOSURE CELL AND SUPPORT AREA GLOVEBOX
}

\author{
Kevin M. Croft \\ Idaho National Laboratory \\ 2525 N. Fremont Ave. \\ Idaho Falls, ID 83415
}

\author{
Scott M. Allen \\ Idaho National Laboratory \\ 2525 N. Fremont Ave. \\ Idaho Falls, ID 83415
}

\author{
Mark W. Borland \\ Idaho National Laboratory \\ 2525 N. Fremont Ave. \\ Idaho Falls, ID 83415
}

\section{INTRODUCTION}

The Yucca Mountain Waste Package Closure System (WPCS) cells provide for shielding of highly radioactive materials contained in unsealed waste packages. The purpose of the cells is to provide safe environments for package handling and sealing operations. Once sealed, the packages are placed in the Yucca Mountain Repository.

Closure of a typical waste package involves a number of remote operations. Those involved typically include the placement of matched lids onto the waste package. The lids are then individually sealed to the waste package by welding. Currently, the waste package includes three lids. One lid is placed before movement of the waste package to the closure cell; the final two are placed inside the closure cell, where they are welded to the waste package. These and other important operations require considerable remote material handling within the cell environment. This paper discusses the remote material handling equipment, designs, functions, operations, and maintenance, relative to waste package closure.

\section{DISCUSSION}

All operations within the closure cells are either robotic or remotely controlled. Handling operations are performed using five primary systems (See Figure 1) associated with the WPCS:

1) Remote Handling System (RHS). An overhead handling system, located inside the closure cell, incorporates a bridge, trolley, vertical telescoping mast, and a tool plate type interface. This interface offers for the use of a detachable six-axis manipulator system, various tools, and end effectors. The RHS is operated remotely and is capable of programmed moves and also teleoperation. Having a 3-ton lifting capacity, the RHS is the prime-mover in the closure cell for material handling and movement. It incorporates a common robotic tool changing interface for material handling operations. The RHS delivers to and receives items from a transfer cart system. The positioning capability of the RHS is enhanced by a special vision system, which is described in another paper at this conference.

2) Glovebox Materials Transfer System. A transfer cart assembly that runs on rails and is powered by a unique synchronous linear motor system (LSM) transfers lids and materials from a support area into the closure cell through a transfer tunnel that is part of a glovebox system. The cart also transfers materials and equipment to and from the closure cell and glovebox for routine and nonroutine maintenance and repairs. The LSM modules are located under the floor of the transfer tunnel and are designed to move the transfer cart without physical attachment and thereby work without breaching confinement. The individual motors of the LSM are readily retrieved from outside confinement for maintenance or repair.

3) Glovebox Handling System (GHS). Similar to the RHS but smaller, the GHS is installed inside the glovebox. It moves materials inside the glovebox and performs pickup and replacement of items to and from the transfer cart.

4) Closure Cell Crane. This remotely operated 15ton overhead crane is provides for heavy lifting scenarios and to assist the RHS in necessary handling situations. It is nonprogrammable.

5) Two Master-slave Manipulators (MSM). Located at the operator corridor wall and protruding into the closure cell, the MSMs support operations within the waste package area of the closure cell, including dexterous operations at the waste package. The MSMs provide a measure of tactile feedback for assisting in specific material handling operations.

In addition to handling equipment, there are also storage racks, tool trays, and drawers for support and storing of tools, materials, and other needed equipment within the cell. Each of these interface with the RHS and/or GHS.

\section{CONCLUSIONS}

Operations within the closure cells are focused on waste package closure. The Idaho National Laboratory (INL) has been tasked with the responsibility of designing and demonstrating a full-scale closure cell for Yucca Mountain.

This paper discusses the material handling philosophy, equipment, and controls to be used in the INL demonstration and ultimately at Yucca Mountain. 


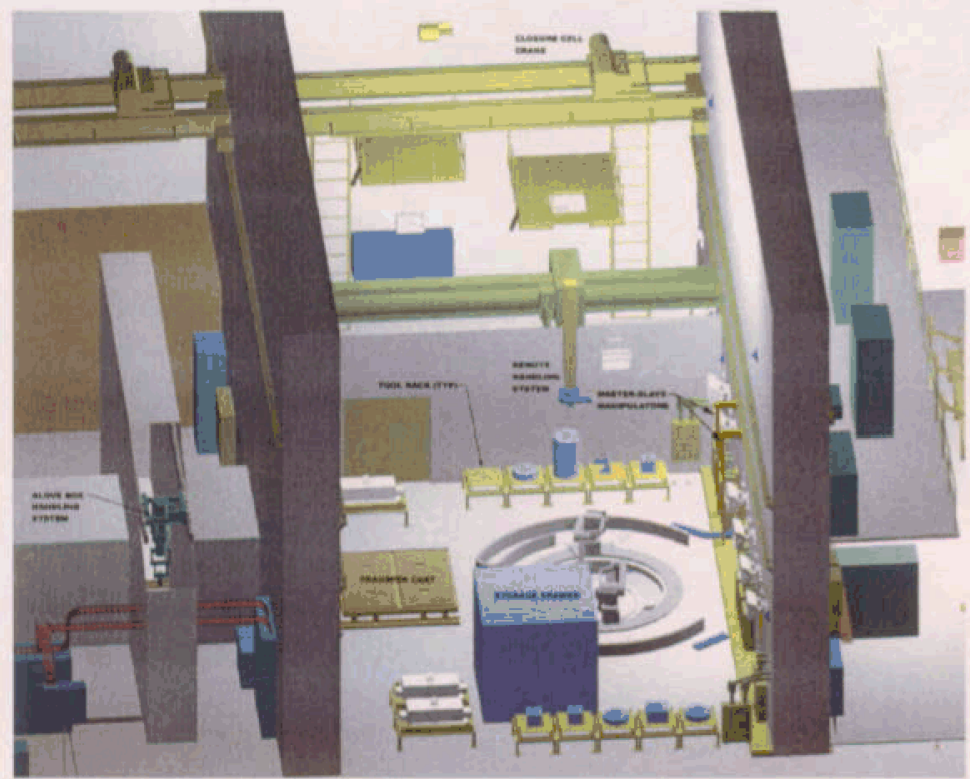

Figure 1. This figure provides a perspective of the Yucca Mountain Waste Package Closure System and associated equipment. 